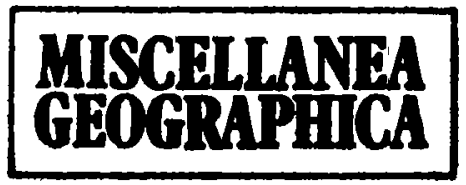

WARSZAWA 1990

Andrzej Kowalczyk

\title{
SECOND HOMES AND FUNCTIONAL CHANGES IN THE SUBURBAN ZONE OF WARSAW
}

The term "suburban zone" covers three basic concepts: (1) outlying district of a town or a city whose demands are taken care of by the town or the city; (2) outlying district of a town or a city as an area which is co-operating with the town or the city; (3) outlying district of a town or a city as an area undergoing changes under the influence of the town or the city (Maik 1985). The suburban zone in the latter sense may thus be defined as a transitory area, i.e. an area in the stage between a town or a city and a village; the transition refers here to spatial as well as socio-economic properties of that zone.

One can differentiate two conspicuous trends in geographical studies of suburban zones - one concentrates on problems pertaining to space (the morphological trend), and the other one deals with functional relations between the suborbs and a town or a city.

The suburbs fulfil several diverse functions, and recreational function can be assigned an important role among them. According to L. Straszewicz (1985), the function of recreation is inseparably related to the notion of the suburban zone; usually, the latter function was prior to all the other ones, such as that of housing and production.

Research into the role of recreational functions fulfilled by the suburbs of big cities has a long-standing tradition. Also in Poland, the latter direction of research is quite well-developed. The most common subject matter of such studies were the suburbs of Warsaw and Łódź (Jasiński, Kowalczyk 1988, Kowalczyk 1987, Liszewski 1985, 1987, Matczak 1986).

At the end of the 19th century, intensive development of recreational functions had its beginning in the vicinities of Warsaw. Before that time, recreational functions had been fulfilled temporarily, and they did not result in any spatio-functional changes that could last 
until today. At the turn of the 20th century, along the railway lines outwards from Warsaw, recreational settlements with second homes owned by the upper class of Warsaw, with boarding houses and hotels, etc., started to develop: Otwock (1876), Anin (1896), Skolimów-Konstancin (1897) and other ones. The rapid pace in which the suburbs of Warsaw were changing at that time can be exemplified by Otwock in 1876 , there were only 18 houses there and 30 years later, there were 600 summer houses and other types of buildings; furthermore, the function of a health resort was also well developed.

The development of the function of recreation performed by the suburban zone of Warsaw continued throughout the 1918-1939 period. These were the times when Podkowa Leśna - "a garden city" was founded; in 1927 - the year when it all began - there were only 17 villas there, but by 1933, 102 second homes and permanent residence houses had been already constructed. Moreover, in the years just before the 2nd World War, several recreational settlements were also founded further away from Warsaw, e.g., Wilga $(60 \mathrm{~km})$, Rybienko (almost $60 \mathrm{~km}$ ), Pomiechówek (45 km). Almost as soon as they had been built, recreational settlements outlying Warsaw started to fulfil a double function - one of recreation and the other of housing. Before the 2nd World War, in the areas most close to Warsaw, a change of the function of recreation into that of housing had already begun (e.g., Anin, Rembertów, Wlochy); the same change could be noted with respect to bigger centres lying just outside the very suburbs of Warsaw (Otwock, Brwinów, Milanówek, Skolimów-Konstancin). After 1945, tendencies of this type were strengthened to a remarkable degree, which was due to almost total destruction of Warsaw that pressed the inhabitants of Warsaw to look for a place to live somewhere in the suburbs - in the areas that survived the war in a better state. Furthermore, in the satellite centres, immigrants from the countryside started to settle down; they found jobs in industry and other branches of the economy in Warsaw that was just being rebuilt. During 1945-1970 period, as a result of the above-mentioned changes, the suburbs gradually lost their original function of recreation and housing and their ample part turned into satellite towns which, either fulfilled the function of housing exclusively, or played some role both in housing and industry. Now a town, Konstancin-Jeziorna can be considered the best example of such transformations; it was founded in 1968, by joining the old health-resort and recreational quarter of Skolimów-Konstancin with the industrial town of Jeziorna and a few countryside settlements. In the suburbs of Warsaw, the role of this town is unique; there are more than 400 second homes; $42.8 \%$ of its professionally 
active inhabitants work in industry and $28.0 \%$ in the health-resort sector (Jasiński, Kowalczyk 1988).

Around 1970, a new phase of spatio-functional changes in the suburban zone of Warsaw began. These were the 1970s that marked the beginning of the second home boom in Poland. Earlier, it was only a small fraction of the society that could afford a second home; however, for the past dozen years or so, ownership of a recreational facility has been a more and more common phenomenon. Pilot inquiry studies show that $10 \%-15 \%$ of Warsaw families have access to a second home (Matulewicz 1986). According to the official data (inadequate since purposefully incomplete), in 1980, there were 41515 second homes; on the other hand, the local authorities of only one community (administrative unit covering a few villages) - Radzymin - claimed that there were about 3,000 summer houses in the very community of Radzymin in 1989. Some reasons for this sudden development of the second home phenomenon throughout the 1970s and the 1980s have been described by many (a sudden increase in the prosperity of the society, development of motor transport, more and more burdensome living conditions in big cities, and the like). However, in the Polish ccntext, this sudden development is conditioned by other factors as well. Since the 70s, in many cities in Poland, and in Warsaw in particular, the housing crisis has become more severe; its results are shortages of flats for young couples and two or more families living in one common flat. Under the circumstances, those second homes, which are much cheaper than a private house or a flat, are treated not only as houses for recreation but also as a place where one of the families can live on its own during a weekend or throughout summer. Moreover, the fact that people want to have a second home or a recreational lot at their disposal may be often considered as a reaction of the society against growing inflation in the Polish economy.

The first characteristic feature of the second home phenomenon to be observed in the suburban zone of Warsaw is an irregular spatial distribution of second homes (Table 1). In the communities north of Warsaw, around Zegrzyński Reservoir and in the valleys of Narew, Bug and Wkra the number of second homes is especially high. The second area with a high number of recreational houses covers woodlands south and south-west of Warsaw (in particular, this includes communities of Nadarzyn, Piaseczno, Lesznowola, Michałowice, and Konstancin-Jeziorna); the 3rd area in the row is the community of Wiązowna in the Swider valley.

The distribution of second homes in Warsaw voivodship is to a large extent conditioned by recreational qualities of the environment, 


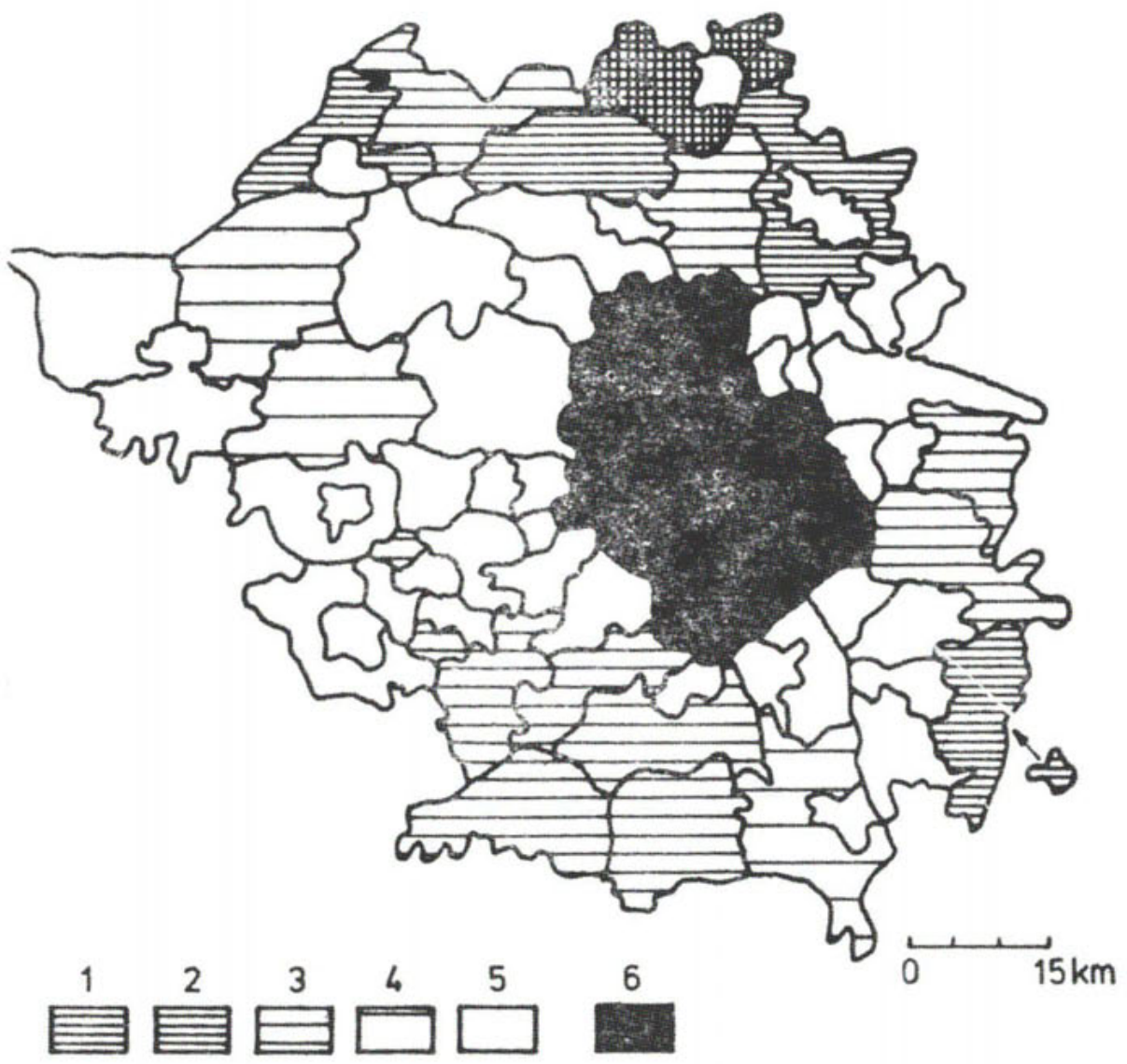

Fig. 1. An area occupied by second homes with respect to the total area of all the communes in Warsaw voivodship (acc. to the data given by the Warsaw Development Planning Bureau for 1982).

Legend: 1 . above $2 \%$ of the area of a commune, 2. from $1.0 \%$ to $1.9 \%$ of the area of a commune, 3. from $0.1 \%$ to $0.9 \%$ of the area of a commune, 4 . below $0.1 \%$ of the area of a commune, 5. areas not planned for recreational housing, 6 . Warsaw.

and especially, by the presence of surface water and woods. Recently, however, one can observe that this constantly growing demand for recreation outside the cities, has been accompanied by the expansion of recreational housing to the areas with almost non-existent recreational qualities. Moreover, second homes are now much more often built far away from Warsaw, and thus the boundaries of the recreational zone of Warsaw are now $50-75 \mathrm{~km}$ away from the centre of the city (a short time ago, they were $25-30 \mathrm{~km}$ away from the city). 
Table 1

The distribution of second homes in Warsaw

Voivodship with respect to types of land USE (1985)

\begin{tabular}{|c|c|c|c|c|c|}
\hline $\begin{array}{l}\text { Commune } \\
\text { (i. e. administrative unit } \\
\text { covering a few villages) of: }\end{array}$ & $\begin{array}{l}\text { approxi- } \\
\text { mate } \\
\text { no. of } \\
\text { second } \\
\text { homes }\end{array}$ & $\begin{array}{l}\text { the } \\
\text { number of } \\
\text { villages } \\
\text { with a } \\
\text { greater } \\
\text { number of } \\
\text { 2nd homes }\end{array}$ & $\begin{array}{l}\text { wood- } \\
\text { land } \\
\text { in } \\
\%\end{array}$ & $\begin{array}{l}\text { crop- } \\
\text { land } \\
\text { in? } \\
q_{0}\end{array}$ & $\begin{array}{l}\text { develo- } \\
\text { ped land } \\
\text { and idle } \\
\text { land in } \\
\%\end{array}$ \\
\hline Brwinów & ? & 2 & 8,9 & 71,5 & 19,6 \\
\hline Celestynów & 50 & 2 & 50,9 & 39,7 & 9,4 \\
\hline Czosnow & $?$ & 9 & 28,4 & 56,6 & 15,0 \\
\hline Góra Kalwaria & 140 & 5 & 21,5 & $6 \overline{3}, 5$ & 13,0 \\
\hline Halinów & 10 & 2 & 15,6 & 75,0 & 9,4 \\
\hline Kampinos & 50 & 2 & 19,5 & 73,6 & 6,9 \\
\hline Karczew & $?$ & $?$ & 5,9 & 77,5 & 16,6 \\
\hline Konstancin-Jeriorna & 170 & 6 & 10,2 & 67,2 & 22,6 \\
\hline Leoncin & $?$ & 4 & 47,2 & 39,7 & 13,1 \\
\hline Leszno & 10 & $?$ & 38,5 & $5 \overline{5}, 7$ & 5,8 \\
\hline Lesznowola & 250 & 5 & 11,2 & 72,9 & 15,9 \\
\hline Łomianki & 220 & 7 & 13,4 & 54.9 & 31,7 \\
\hline Michalowice & 300 & 1 & 7,9 & 67,5 & 24,6 \\
\hline Nadarzyn & 220 & 4 & 20,1 & 69,2 & 10,7 \\
\hline Piaseczno & $?$ & 7 & 33,2 & 52,4 & 14,4 \\
\hline Pomiechówek & 810 & 4 & 28,9 & 58,4 & 12,7 \\
\hline Prażmów & 160 & 5 & 20,5 & 71,2 & 8,3 \\
\hline Radzymin & 1800 & 6 & 22,8 & 65,6 & 11,6 \\
\hline Raszyn & 260 & 2 & 12,0 & 73,6 & 14,4 \\
\hline Serock & 1000 & 11 & 20,1 & 75,2 & 4,7 \\
\hline Skrzeszew & 2500 & 8 & 25,7 & 49,8 & 24,5 \\
\hline Stare Babice & $?$ & 8 & 41,2 & 46,4 & 12,4 \\
\hline Tarczyn & 120 & 3 & 13,5 & 78,6 & 7,9 \\
\hline Tułowice & 10 & 3 & 32,2 & 53.7 & 14,1 \\
\hline Wiązowna & $4 \cdot 0$ & 7 & 34,7 & 57,4 & 7,9 \\
\hline Zakroczym & ? & $?$ & 14,7 & 71,6 & 13,7 \\
\hline
\end{tabular}

Notes: (1) the table does not include towns

(2) in communes not mentioned here, there were no second homes or just a few.

The second characteristic of housing in the suburbs of Warsaw is a remarkable diversity in the size of second homes, in their technical standard as well as in the area of a recreational site. Generally, in the case of old recreational areas of the 19 th century and the pre-2nd World War period, there are more large buildings fit for living throughout the whole year. Konstancin-Jeziorna, Zalesie Górne, Eomianki or Józefów all exemplify the fact that a greater number of 
second homes is being transformed into permanent residence houses. This refers, in the first place, to buildings owned by the members of the upper classes, by pensioners and the like who also have flats of their own in Warsaw. On the other hand, in the case of the residential centres that were founded a few years ago, second homes for weekends and vacations predominate. They are usually smaller, made of wood, with no systems indispensable for spending the winter there. Detailed studies conducted in the commune of Konstancin-Jeziorna and Nieporęt have shown that the average floor area of second homes in the old settlements (the town of Konstancin-Jeziorna) is almost $73 \mathrm{~m}^{2}$ while that of second homes built recently in new quarters 25-30 $\mathrm{m}^{2}$ (Białobrzegi, Czarnów, Stanisławów) or up to $40-45 \mathrm{~m}^{2}$ (Rynia, Kierszek). The same differences characterize the size of recreational lots in Konstancin-Jeziorna: the average area of a lot is about $2,000 \mathrm{~m}^{2}$, but in new quarters that were founded in recent years or so, such as Rynia, Białobrzegi and Beniaminów, the site area is from $800 \mathrm{~m}^{2}$ up to $1,100 \mathrm{~m}^{2}$.

The above-mentioned phenomenon, which may be interpreted as differentiation of second home centres in terms of "better" and "worse" ones, is also reflected in the prices of recreational real estates. At the turn of 1989, the average price of a site in Podkowa Leśna, Magdalenka or Konstancin-Jeziorna was up to $6-8$ dollars for $1 \mathrm{~m}^{2}$ while in new sites, which are usually further away from Warsaw, the price of $1 \mathrm{~m}^{2}$ was about $1-2$ dollars (the prices are in dollars because, due to inflation, this was the currency of sales).

The third distinguishing feature of the second home phenomenon to be observed in the Warsaw region, is a spontaneous character of recreational housing; and this means that many recreational housing constructions (or even recreational settlements) are being built in areas which are not included in town planning projects for housing of this type; quite often this is being done even if it is clearly against the law. As a result, many conflicts appear; also, the natural environment deteriorates constantly, water resources are being depleted, vegetation is being ruined, and so on.

The fourth and the last feature of recreational settlements in the suburban zone of Warsaw, which is characteristic of many settlements is mixing several functions together: recreational, agricultural, that of service or even the one of industry. The economic crisis has pressed many owners of second homes to take some economic actions so that the costs of the site or the building would pay back. In most cases this 
is vegetable and fruit growing for one's own needs, but in many suburban regions the activity takes up the form of commodity production. There are also owners who open car services, cafés, rent rooms or start a small business in industry. Most clearly, this intermixing of recreational and recreational-housing functions with service and industrial functions can be observed in some quarters that were founded before 1939 (Józefów, Podkowa Leśna, Łomianki, Dąbrowa, Konstancin-Jeziorna). On the other hand, in the case of those residential quarters which not long ago were regular villages, second homes have usually assumed agricultural function.

As the above described phenomenon tends to spread, one can predict that in the near future a great part of present "second home" quarters will be transformed into the suburbs with well-developed functions of housing and services or housing and industrial functions, and, at the same time, the recreational function will gradually disappear. This was the development of several old recreational settlements which had been engulfed by Warsaw during 1918-1939 period and just after the 2nd World War. This situation is now even more feasible when we consider the fact that some recreational centres have been granted the city status recently; and, in the Polish context, having the city status limits recreational functions and restricts building second homes. This trend in the development of the suburban zone of Warsaw is in full agreement with predictions on spatial development of urban regions. In geographical literature, such trends have been considered as one phase in the development of urbanized areas (Clout 1974, Vedenin 1982). The claims are being made here that, as a result of spatio-functional changes in the suburbs, some old functions of suburban districts give way to some new functions, and, by the same token, the zone affected by a town or a city moves further away from the centre of the urban area. Consequently, under the dynamic concept of urbanization, second homes constitute a certain transitory stage in the process of spatial expansion of a town or a city.

\section{REFERENCES}

Clout H., 1174, "The growth of second-home ownership: an example of seasonal urbanization", in: Suburban growth. Geographical processes at the edge of the Western city, Johnson J. H., (ed.) John Wiley and Sons, pp. 101--127.

Jas iński A., Kowalczyk A., 1988, "Konstancin-Jeziorna. Monografia miejscowości turystycznej", (Konstancin-Jeziorna. The monography of tourist settlement), Wydział Geografii i Studiów Regionalnych, Uniwersytet Warszawski, mimeo. 
Kowa lczyk A., 1987, „Model lokalizacji wypoczynku podmiejskiego (na przykładzie Warszawy)", Materiały 36 Ogólnopolskiego Zjazdu PTG, Sosnowiec, 23-26. 9. 1987, (The model of localization of suburban recreation (an example of Warsaw), Proceedings of 36th Polish PTG Conference, Sosnowiec 23-26. 9. 1987), pp. 104-106.

Liszewski S., 1985, "Użytkowanie ziemi jako kryterium strefy podmiejskiej", (Land use as a criterion of the suburban zone), Acta Universitatis Lodziensis, Folia Geographica 5, pp. 75-90.

L iszewski S., 1987, "Geneza i rozwój osadnictwa wypoczynkowego w otoczeniu Łodzi," (The origins and the development of the recreational settlement around Eódź), Acta Universitatis Lodziensis, Turyzm 3, pp. $34-54$.

Maik W., 1985, "Charakterystyka strefy podmiejskiej w kategoriach funkcjonalnych. Próba rekonstrukcji modelu pojęciowego i metody badawczej": (Description of the suburban zone in its functional categories), Acta Universitatis Lodziensis, Folia Geographica 5, pp. 41-60.

Matczak A., 1986, "Budownictwo letniskowe $w$ strefie podmiejskiej Eodzi", (Recreational housing in the suburban zone of Łódź), Acta Universitatis Lodziensis, Folia Geographica 7, pp. 137-166.

M a t u lewicz K., 1986, "Próba określenia przestrzennych preferencji wypoczynkowych mieszkańców Warszawy", (Spatial preferences of recreational needs of Warsaw inhabitants), Wydział Geografii i Studiów Regionalnych, Uniwersytet Warszawski, mimeo.

Straszewicz L., 1985, "Strefa podmiejska. Pojęcia i definicje" (Suburban zone. Concepts and definitions), Acta Universitatis Lodziensis, Folia Geographica 5, pp. 7-16.

Vedenin Y. A., 1982, Dinamika territorialnych sistem, (The dynamics of territorial recreational systems), Nauka, Moskva. 